\title{
Design of the Elements of Real Estate Tax on Possession from Real Estate Tax in the UK
}

\author{
Yan Huang \\ Shandong Technology and Business University \\ Yantai, China
}

\begin{abstract}
There exist problems that the fiscal revenue and expenditure authority are not asymmetric in China's local governments for a long time. It also has aggravated a complicated situation to the imbalance between supply and demand in the real estate market, making it more difficult for the central government to control market. The reform of present tax type and introduction of real estate tax on possession can not only provide a stable source of income for the local government, but also adjust the cost composition of real estate, which is conducive to the healthy development of the market. The mature real estate tax in the UK has a strong reference in terms of functional localization, tax base determination, tax authority division and tax collection, which can bring enlightenment to the design of elements of real estate tax in China.
\end{abstract}

Keywords-real estate tax in the UK; on possession; tax system elements; local financial revenue

\section{INTRODUCTION}

A complete tax system includes three major tax types, that is, turnover tax type, income tax type and property tax type, and other auxiliary tax types including behavior tax. Comparing the tax systems in various countries, turnover tax types mainly include value-added tax and business tax, and income tax types mainly include individual income tax and social security tax. While the property tax is designed based on each country's own national conditions, and the real estate tax is mostly the main tax type of property tax and is an important part of the complete tax system.

The levy of tax on real estate in China is distributed in many types of taxes, including house property tax levying on house, urban and rural land use tax levying on land-use right, land value increment tax levying on income from land value increment, and local government's land-transferring income with land rent as a essence. Among which, the most important ones are house property tax and land-transferring fees: house property tax is a tax that takes house property as object of taxation and is levied on the owner of title on the basis of the taxable residual value or rental income of the house. Landtransferring fees are that land administration departments of governments at all levels lend land use rights to the land user, collect all the payments (which refers to total transactions of land grant) by land grant from transferees according to provisions, or at the expiration of land use, the land users need to renewal and pay transferring fees of extending the validity for land administration departments, or the land users who gain land use rights through administrative appropriation will hand in retroactively the transferring fees as required by transferring, leasing, mortgaging, buying a share and investing.

\section{The EXISTING Problems OF THE CURRENT REAL ESTATE TAX IN CHINA}

At present, there are many problems in the real estate market in China, such as ever-increasing housing price, while macroeconomic regulation and control is basically ineffective, and the public is questioning the government. There is an imbalance between supply and demand in real estate market, and the actual house demander cannot afford to buy houses because the housing-price-to-income ratio is excessively high and deviates from the reasonable proportion scale. Worse still, the continuous rapid growth of housing price makes investment capital be input, and the supply of commercial housing is rising firmly, which has cause "drawing blood" for capital investment of other industries. Real estate generates huge bank loans in both investment and consumption links, and the "bubble" of false economic growth and the systemic risk in credit market also increase. The out-of-control real estate market makes the local government seek a "shortcut" for rapid expansion. The increasing land price not only promotes the disordered competition between local governments, but also inspires local governments to resist the central government' macroeconomic regulation and control.

Facing with the disordered market, redesigning the current taxation system of real estate and adjusting market failure become increasing necessary. The current real estate tax still has many problems:

\section{A. Unclear Functional Localization of the Current Real Estate Tax}

As an important tax type of property tax, house property tax has the multiple functions that stabilize financial income and adjust the gap between the rich and the poor. Under the current system, the levy of tax on real estate is scattered in multiple fiscal revenue fields, making the function localization unclear, such as the function of stably increasing fiscal revenue. Currently, the house property tax has the characteristics of narrow tax base, light tax burden and poor tax revenue elasticity, and the income cannot be guaranteed. Although the land-transferring fee continues to rise and even becomes the main income source for local governments, as a fund income, it does not have the authority to impose legislative restrictions 
on taxation, and it has great uncertainty and the concealment of local government's distribution on this income. In terms of adjusting the gap between the rich and the poor, the narrow tax base violates the principle of "universal levy" on tax. It cannot achieve a real and effective adjustment of income distribution horizontally and vertically.

\section{B. Obsolete Design of the Existing Real Estate Tax Can Not Reflect the Principle of Fairness and Efficiency of Revenue}

First, the above-mentioned tax types will basically produce rateability in the investment, transaction and operation process, put emphasis on turnover rather than possession, and seldom involve possession link but repeatedly collect taxes for turnover link.

Second, taxable method is obsolete. For instance, house property tax regards original value as taxation basis and does not completely take into account the overall increase in the real estate price every year. Other taxes that take rent as taxation basis do not deduct the effect of inflation.

Third, due to the dualistic land system in China, all the current taxes take real estate in urban areas as tax base and rarely involve the real estate in rural areas. However, the ultrahighspeed of urbanization will bring the added value of rural land value.

Fourth, at present, for the so-called "limited property house" that has largely existed; there are no good plans about how to solve stock and limit increment.

In 2017, the total GDP of China reached 13,173.585 billion US dollars, second only to the 19,555.874 billion US dollars of America. However, as the largest population country in the world, China accounted for $18 \%$ of the world's population in 2017, however, the per capita income still belonged to a developing country. Besides, the cultural background of China differs from the West, so people's taxation ideas are also different from the West. Therefore, a complete real estate tax that meets the principle of "fairness and efficiency" of taxes cannot completely and simply refer to the tax system of other countries, and can only selectively gain successful experiences from other countries.

\section{BRIEF INTRODUCTION TO TAX SYSTEM ELEMENTS OF REAL ESTATE TAX IN THE UK}

From the perspective of theory of public economics, an ideal tax type should meet the principle of universal collection, that is, the scope of the levy of tax should cover all taxpayers, and no special provisions exist such as excessive immunity, exemptions, special tax rates, etc.; horizontal equity, that is, the taxpayer with equal income should have equal tax burdens, and no regressive phenomenon exists; vertical equity, that is, taxpayer can pay taxes based on his ability, which is conducive to alleviating the gap between rich and poor; tax neutrality, which will not distort economic activities and reduce economic efficiency; low cost of collection and taxation, easy collection and management and so on. However, in the practice of tax, it is hard to meet all the conditions at the same time. The real estate tax includes two levels of taxation, that is, house and other attachments to land and land. From the perspective of legal rights, it includes the taxation of ownership and use rights. And the taxes can be divided into the following types according different situation of different countries.

British real estate tax headed by the UK is the levy of tax on ownership and use rights of real estate. The owner and actual user of the real estate pay the property tax to the taxpayer.

In terms of land tax headed by Germany, it only levies tax on land increment, so as to reduce the gap between the rich and the poor caused by the "an unearned income with land increment".

For the real estate tax in macro-control type headed by Japan and South Korea, the main purpose of the levy of tax is to regulate housing prices, and use multiple taxes to adjust the real estate market.

Comparing several models, Germany, which has implemented a single land tax, has to seek the reform of real estate tax due to the difficulty in updating its cadastral value. Japan and South Korea have very limited effects on the regulation on the real estate market through taxation. The UK is the first country to levy the real estate tax, therefore, its tax system has great reference significance in terms of function positioning, factor design, and collection and management system.

A. The Real Estate Tax in the UK Aims at That Grassroots Local Governments Provide Public Services to Raise the Fiscal Revenue, Take Market Assessment Value as Tax Base, and Determine Income Through Expenditure and Stabilize Tax System

The expenditures of local government are mostly public projects in this region, or public services or public goods, which has strong rigidity and regional coverage. With economic development and rising prices, local governments need sustained and stable fiscal revenue to maintain the normal functioning of local government functions. The tax base of house property tax is fixed and difficult to turn over, and its tax fund is open for tax authority and easy to collect and manage. At the same time, it is also open for other taxpayers in this region and easy to be supervised by the public; the taxation basis of house property tax is the evaluation value. Due to the existence of the evaluation cycle, the fluctuation in the economic cycle will be lower than the general commodity price, cash income and other capital gains, and the income is relatively stable; the tax base of house property tax is the fixed beneficial owner of the public services in the region. There is a strong correspondence between tax revenues and expenditures, and taxpayers can directly benefit from the various services provided by the local governments, so their tax compliance is relatively high. Therefore, real estate tax has the natural advantages of the local government's important source of tax revenue.

The real estate tax in the UK can be divided into the residential tax of its own residence - the council tax and the non-residential tax for business purposes - the non-domestic rating. The tax base of council tax is the estimated value of 
house recognized by the appraisal agency authorized by the tax department, and the excess progressive tax is paid by the different house grade, and the specific tax rate is determined by the local governments of the UK. The collection basis of the business tax is the annual net income of the house, that is, the annual rent minus the repair cost of the house. The tax rate is determined by the central government, and different tax rates are applied according to the application of the house.

Council tax is the largest local tax type in the UK. For example, in 2012-2013, the local government collected a council tax revenue of 26.7 billion pounds, accounting for $54.8 \%$ of the local government's self-raised income, accounting for $17.2 \%$ of the local total income. In the central government's subsidies, the returned non-domestic rating and property tax revenue are 23.1 billion pounds, accounting for $14.9 \%$ of the total revenue of the local government. The nondomestic rating has been classified as a central tax type since 1990. The non-domestic rating revenue collected by the local government will be remitted to the special fund after handing over to the central government. According to the population base in China, the central government will take the fund as the payment transfer fund, and reallocate it in proportion in various region, and the tax is finally returned to the local finance for a special use. After returning, the non-domestic rating revenue accounts for about $1 / 4$ of the central government's transferring funds to local governments, and accounts for more than $15 \%$ of the total local fiscal revenue. It can be seen from this that the functional positioning of the real estate tax in the UK is very clear, that is, to raise fiscal revenue for local finance.

\section{B. Tax System Elements of Real Estate Tax in the UK}

After clarifying the functions of tax types, we will survey the subject to taxation, tax base, tax rate and other tax system elements of real estate tax in the UK.

1) Subject to taxation and tax base: The taxpayer of the council tax is the housing owner or tenant who is over 18 years old, and the subject to taxation is the residential house. The subject to taxation of Non-domestic Rating is commercial real estate, such as shop, office building, warehouse, factory or other non-residential real estate. From this point of view, the real estate tax in the UK is a levy of tax on the ownership and use right of real estate.

According to the local tax law in the UK, local governments regularly update and grade the value of taxable residences. At present, the valuation criteria used in the UK is the market prices that taxable residential properties assumed to sold on April a, 1991. In view of the principles of fair taxation and convenient taxation, the UK has designed eight grades (see Table I for details) from $\mathrm{A}$ to $\mathrm{H}$ based on the value of house property, which assume progressive rate respectively.

Deng Juqiu, Zhu Keshi. The Functional Positioning of Real Estate Tax in the UK and Its Enlightenment [J]. Taxation Research, 2015 (12): 8285.
TABLE I. GRADING StANDARDS For THE VALUE OF RESIDENTIAL REAL ESTATE IN VARIOUS REGIONS OF THE UK (POUND)

\begin{tabular}{|l|l|l|l|}
\hline Grading & \multicolumn{1}{|c|}{ England } & \multicolumn{1}{c|}{ Wales } & \multicolumn{1}{c|}{ Scotland } \\
\hline A & $<40000$ & $<30000$ & $<27000$ \\
\hline B & $40000-52000$ & $30000-39000$ & $27000-35000$ \\
\hline C & $52000-68000$ & $39000-51000$ & $35000-45000$ \\
\hline D & $68000-88000$ & $51000-66000$ & $45000-58000$ \\
\hline E & $88000-$ & $66000-90000$ & $58000-80000$ \\
& 120000 & & \\
\hline F & $120000-$ & $90000-$ & $80000-106000$ \\
& 160000 & 120000 & $106000-212000$ \\
\hline G & $160000-$ & $120000-$ & \\
\hline H & 320000 & 240000 & $>212000$ \\
\hline \multicolumn{4}{|c|}{ a. Data source: Citizens Advice Bureau.UK } \\
\hline
\end{tabular}

2) Tax rate and tax payment stages: According to the eight grades above, the tax law stipulates that the house property with D-grade as a benchmark grade, a tax rate of 1 , and lowest grade as A- grade, will be levied a tax at 6/9 of Dgrade, and the house property with a more grade will be multiplied in proportion. For details, seeing "Table II".

TABLE II. TAX STANDARDS FOR EACH GRADE

\begin{tabular}{|c|l|l|l|l|l|l|l|l|}
\hline Grade & A & B & C & D & E & F & G & H \\
\hline Ratio & $6 / 9$ & $7 / 9$ & $8 / 9$ & 1 & $11 / 9$ & $13 / 9$ & $15 / 9$ & 2 \\
\hline \multicolumn{1}{c|}{ a. Data source: Valuation Office Agency of theInland Revenue.UK }
\end{tabular}

According to the needs of the financial expenditure at local level, the local government adjusts the ratal of residential tax at each grade every year. Judging from the situation in recent years, the ratal of council tax in the UK has been increasing year by year.

From the perspective of tax payment stages, council tax is a tax that is levied on the possession of real estate. It focuses on the possession rather than obtain which is conducive to the flow of real estate and can avoid owner's low-efficient utilization due to vacant properties. Therefore, the real estate tax system in the UK is in line with the efficiency principle, which facilitates the realization of distribution effect of residents, and effective allocation of source for real estate tax efficiency, so as to achieve the rational development of the real estate market.

3) Tax preference and exemption: The tax preference of council tax in the UK can be divided into three aspects:

First, they provide tax exemption for low-income people. That is to say, Individuals with assets (deposits and investments) of less than 16,000 pounds and individuals enjoying subsidies and preference can apply for tax deductions from the local government.

Second, special populations who meet the requirements, such as the disabled, juveniles, students, patients, and other people who have no income, can enjoy tax preference.

Third, the vacant homes that are not in use can have a tax exemption for up to six months and a 50\% tax deduction after the expiration.

From these policies, it can be seen that in terms of the tax preference provided in the municipal tax by the UK on the basis of broadening tax base, the UK mainly considers the 
taxpayer's income ability and current payment ability, and fully takes into account the issue of social equity, so as to ensure tax fairness to a great extent.

4) Tax collection and management: As a direct tax, real estate tax has a high cost of collection and management, and it is a great test for the level of government's collection and management. It is an unavoidable problem in the real estate tax how government accomplishes the tax task with the lowest tax cost, and how the taxpayer assumes the tax obligation with the lowest tax cost.

For the value evaluation of real estate, the value evaluation of real estate that the UK has adopted as taxation basis of municipal tax is evaluated by the housing appraisal agency affiliated to the UK Inland Revenue, unless under special circumstances, it should be evaluated in every 5 year. However, Non-domestic Rating should reappraise the taxable value of commercial house property in every 5 year and update the taxation list. According to statistics, the housing appraisal agency affiliated to the UK Inland Revenue has aggregated 2 million real estate transactions each year, thus forming a comprehensive real estate valuation system in various regions of the UK. It can be seen that the UK's tax base valuation is carried out by the central government, while the specific collection and management is done by the local government.

About dispute resolution, the real estate tax is different from the indirect tax such as value-added tax. Its direct taxpayer is highly sensitive to the tax burden of real estate tax, and it puts high demands on the transparency and fairness of the real estate tax. Therefore, the real estate tax is a tax type with more tax revenue disputes. In the UK, when taxpayers disagree with the grading of residence in the assessment results, usually, they can directly go to the local assessment office to raise objections. The taxpayer needs to verify the housing information provided and explain the reasons for the objection. The assessment office will give advice within two months. At a higher level, taxpayers can also file lawsuits with the courts to settle disputes.

\section{SOME ENLIGHTENMENT to THE DESIGN OF ELEMENTS OF REAL ESTATE TAX IN CHINA}

The UK is a country with relatively high fiscal centralization. Its real estate tax system is relatively mature, and has a strong reference for China. However, China still has some national conditions that are completely different from those of Western countries. The author believes that the real estate tax in the UK can be explained from the following points:

\section{A. The Real Estate Tax Needs Perfect Legislation to Support It}

The legislation on real estate tax not only requires independent tax law legislation, but also requires a series of other legislation to support it under China's current tax collection system.

First of all, it is the local government's legislation on the right to fiscal revenue at the local level. Although the rate range of house property tax rate can be uniformly divided by the central government, we need to grant legislative power to the local government in terms of the specific total tax and implementation tax rate in the region.

Secondly, it is about the two-dimensional land rights of urban and rural area. National tax revenue is required to be horizontally fair to the whole people, so we need to re-enact legislation on the property rights of rural real estate. The author believes that we can indirectly solve the legitimacy problem of limited property house by differentiating the exemption area of limited property house without a complete property right by means of the levy of tax on real estate. That is to say, commercial housing with complete property rights can gain more exemption area, while the limited property house can only have relatively small exemption in area.

Thirdly, it is the legislation on the merger of taxes and fees. The essence of the land transferring fees of the local government is the one-time realization of land rent in the transfer period. If we levy a tax on the real estate on possession, the essence is that the government levies a tax on the annual real estate revenue, so the two need to be unified from the legislation.

\section{B. The Real Estate Tax Should Be Located in Raising Revenue for Local Governments}

Although people hope that real estate tax can regulate income distribution and control the growth of housing price, especially the market regulation theory. Certainly, the increase of the possession costs will increase the capitalization of real estate value to reduce the housing price, but there are many factors affecting the housing price, including the market demand, number of investment channel choice, and beforementioned impulse of local government expansion. The practical effects of these functions are very limited from various countries' practice. Therefore, China can learn from the UK in the real estate tax, and the original legislation should be located in raising financial revenue for the local government. At the same time, we should also consider the local tax competition that may be caused, strengthen the supervision of the central government to the local governments, and improve the vertical transfer payment.

\section{Tax Base Assessment of Real Estate Tax}

On the basis of the current tax system design of various countries, tax base assessment roughly includes two modes, namely, establishment of assessment agencies by the government, and authorization of other market assessments. The advantage of the government's establishment of an assessment agency is that we can avoid violations of market assessment, and the disadvantage is that the cost is high and it is vulnerable to be interfered from tax department and thus loses its fairness. Considering that the assessment market in China has not started for a long time, it is recommended to adopt a combination of government and market. That is to say, in areas where market development is good and its conditions are favorable, market assessment agencies are authorized, and in area where conditions are not favorable, the government establishes an assessment agency independent of the tax departments to complete the tax base assessment. 


\section{Real Estate Tax Preference and Exemption}

The most controversial area of real estate tax is that the per capita income now is still relatively low in China, and the housing-price-to-income ratio is much higher than the international average. The levy of tax on the real estate on possession has the social effect of negative income distribution, so the design of tax preference and exemption is particularly important. If we adjust the market supply and demand as a function positioning, the exemption scope will be certainly controlled. However, if aiming to raise income, we must consider both the fiscal revenue in the current period, and land increment in the region and income levels and taxable capacity of local residents in the long period. Therefore, in the initial stage of the implementation of real estate tax, we should give a larger range of deduction or exemption on the basis of broadening the tax base.

\section{E. The Information Sharing and Dispute Settlement of Real Estate Tax}

The real estate in China has the characteristics of large market, more taxpayers involved, complex taxation capabilities of taxpayers, and foreseeable tax dispute is a matter that must be treated with caution. First of all, it is necessary to minimize the total amount of tax disputes, and information sharing is an effective way. The information sharing network will be established nationwide. The information department will take the lead in establishing a national information sharing network for real estate in the cooperation of real estate, industry and commerce, finance, taxation and other departments, to realize transparency and openness of information on the basis of the national real estate tax base assessment network. Next, disputes are resolved at different levels after the dispute has arisen. A relatively independent evaluation agency will protest an objection at the grassroots level, and an administrative review organ will be established at the middle level, and finally the disputes will be adjudicated and settled by the law.

\section{CONCLUSION}

As the saying goes, another's good quality or suggestion whereby one can remedy one's own defects. There are many unavoidable difficulties to be solved in the design of real property possession tax in China, and China can also draw inspiration from successful experiences of other countries. The new real estate tax will be set as the main tax types of local, and the tax base assessment criteria for rural and urban areas will be unified. On the principle of broadening tax base, we will design a reduction and exemption that meets the taxable capacity of taxpayers in China, establish a national shared information network, and clearly solve the hierarchical structure with tax dispute. We try to start from a new perspective, which not only is conducive to solving the serious imbalance between income and expenditure of the local government, but also better achieves tax fairness.

\section{REFERENCES}

[1] Li Changsheng. Research on International Comparison of Functional Orientation of Real Estate Tax [J]. Reform of Economic System, 2017 (06): 166-170.

[2] Fan Hua, Ye Yanmei. A Brief Introduction of Real Estate Tax System in the UK [J]. International Taxation In China, 2005 (04): 42-45.

[3] Deng Juqiu, Zhu Keshi. The Functional Positioning of Real Estate Tax in the UK and Its Enlightenment [J]. Taxation Research, 2015 (12): 8285.

[4] Man Yanyun, He Yang, Liu Wei. National Comparing Articles of Real Estate Tax (I) Several Keywords of Function Positioning of Real Estate Tax [J]. International Taxation, 2014(10):54-58.

[5] Zhang Pingzhu. Research on the Assessment of Tax Base of Real Estate [D]. Xiamen University, 2007.

[6] Su Jingchun. A Review of International Experience in Real Estate Tax and Its Reference - Taking Eleven Countries and Regions around the World as Examples [J]. Review of Economic Research, 2015 (71): $37-$ 45.

[7] Liu Can, Han Wenlong. What Is the Way for the Houses with Limited Property Rights? An Analysis from the Perspective of the Property Right Economics [J]. Contemporary Finance \& Economics, 2013 (02): $5-15$ 